\title{
Do carrier expectations indicate industry structure in container shipping? An econometric analysis
}

\author{
Michael Fusillo ${ }^{1}$ and Hercules Haralambides ${ }^{2,3^{*}}$ (D)
}

\author{
*Correspondence: haralambides@ \\ ese.eur.nl \\ ${ }^{2}$ School of Maritime Economics \& \\ Management, Dalian Maritime \\ University, Dalian, China \\ ${ }^{3}$ Department of Engineering \\ Technology and Industrial \\ Distribution, Texas A\&M University, \\ College Station, USA \\ Full list of author information is \\ available at the end of the article
}

\begin{abstract}
In the competitive environment of liner shipping, the ability to nimbly adjust shipping capacity to demand could mean the difference between a thriving shipping operation and one that will most likely fail. How quickly and effectively carriers adjust their capacity may depend on how their expectations regarding trade volumes and freight rates are formed. We find that if adaptive expectations prevail in the decision process, capacity deployment may suffer some degree of inertia but, compared to expectations that are formed rationally, capacity would be be relatively stable. On the other hand, if carrier expectations are rational, capacity deployment might be more likely to align closer and faster with demand. We seek to empirically test whether carriers' expectations of demand, aiming at deploying the right amount of capacity, can be characterized as adaptive or rational. We find that a) in most cases, adaptive expectations is the paradigm in container shipping; b) the way expectations are formed and the market structure of the liner shipping industry are two things not totally unrelated; and c) rational expectations point to more competitive markets (such as that of the Pacific), while adaptive expectations indicate higher concentration and thus imperfect competition (as is the case in the North Atlantic). Our findings have important regulatory implications in the sense that, if one accepts, as we do, that adaptive expectations are consistent with concentrated industries, while rational expectations suggest more competition, then our paper suggests that the 2008 abolition of the liner conference system from European trades has failed to improve the level of competition in the Europe - US liner shipping markets.
\end{abstract}

Keywords: Liner shipping, Container shipping, Liner conferences, Freight rate fluctuations, Rational expectations, Adaptive expectations, Regulation in shipping, Liner consortia block exemption, Market structure

\section{Introduction}

Economic agents who consistently make well-informed decisions based on accurate and cost-effective forecasts are bound to prosper (Orazem and Miranowski 1986). It should be obvious to all, therefore, that profitability, if not firm survival by and large, lies behind the way a company forms its expectations (forecasts). Needless to say of course that the consequences of incorrect projections of key variables, especially if errors are systematic and persist over time, are more severe for firms operating in competitive industries than those operating in less competitive and thus more forgiving

(c) The Author(s). 2020 Open Access This article is distributed under the terms of the Creative Commons Attribution 4.0 International License (http://creativecommons.org/licenses/by/4.0/), which permits unrestricted use, distribution, and reproduction in any medium, provided you give appropriate credit to the original author(s) and the source, provide a link to the Creative Commons license, and indicate if changes were made. 
environments. As the accuracy of predictions can vary depending on how expectations are formed, it is reasonable to assume that the way expectations are formed may be indicative of the level of competition in a particular industry. This is the hypothesis we are modelling and testing below, in the case of liner shipping.

In liner shipping, the balance of supply and demand is a critical parameter in the determination of the direction, level and stability of freight rates (Haralambides et al. 2003). However, given the nature of the service and the uncertainties of international trade, excess capacity in container shipping has allegedly become a permanent feature of the industry; a persistent threat to the stability of freight rates; to profitability; and even to carrier survival. ${ }^{1}$ In today's operating environment, where collective pricesetting is prohibited in two of the three major east-west trade routes, decisions that determine the level of operating capacity are critical to carriers' financial well-being. This said, however, the proliferation of a quasi-permanent excess capacity in the industry suggests that carriers tend to systematically overreact to positive demand growth signals, and they fail to react timely and sufficiently when demand retreats. The persistence of excess capacity, it seems, can partially be traced to the quest for economies offered by increasingly larger vessels, as well as to the costs and complexity associated with removing existing but smaller vessels from service, or cascading them to peripheral markets.

The questions asked in this paper regard the way expectations of demand in liner shipping are formed, and the possible link between expectations and industry structure. Rational expectations, which are consistent with optimizing behaviour (Muth 1961), should normally prevail in today's more competitive and also more uncertain environment of the liner shipping industry. We find that this may not be always true, and global shipping alliances may have something to do with it. Adaptive expectations, in which the agents' forecasts of key variables are based exclusively on past observances with no regard to current conditions, are more likely to have prevailed in the era of collective price-setting of liner conferences.

To address these issues, we carry out an empirical analysis using quarterly data of liner shipping supply and demand, for the aggregate US liner shipping market and for the two major US east-west trade lanes (i.e. Pacific and Atlantic). The paper's key innovation is to show that the way expectations are formed can hint to the level of competition in the industry. To a policy maker or a market regulator this is important information as well as a 'tool'.

The remainder of the paper is organized as follows. We begin with a discussion and graphical analysis of liner shipping capacity and demand and we subsequently describe their performance across different regulatory regimes. A section on expectations develops the models to be tested, data and market definitions offer a detailed outline of the data set and finally we provide a discussion of our results before drawing our conclusions.

\footnotetext{
${ }^{1}$ The 2016 collapse of Hanjin Shipping is one glaring example that was several years in the making. It can be traced primarily to overinvestment in "megaships" at the time of the financial crises in the US (2008/09) and Eurozone (2010), and to the slower economic growth in China beginning in 2010. Each of these developments depressed demand growth to levels far below what the company had anticipated when making its investment decisions (see https://www.joc.com/special-topics/hanjin-shipping-bankruptcy for a timeline of events leading up to declaration of bankruptcy).
} 


\section{Liner shipping capacity and demand}

Operational excess capacity is a well-known, and one might say a quasi-permanent feature of liner shipping. Explanations can be traced to the peculiar nature of the service, characterized by fixed sailing schedules (cf. fixed costs) on the supply side (lumpy capacity), and the seasonal peaks and troughs of (an inelastic) demand. Excess capacity tends to suppress freight rates, cut carrier profits and erode the industry's ability to deliver prompt and reliable services to shippers. Notwithstanding this, the urge of individual carriers to ensure competitiveness (as well as market share) through scale economies, allegedly achieved by larger vessels, is unrelenting.

Larger ships and high frequency of service -the latter as demanded by the shippers themselves- mix an explosive cocktail, challenging the ability of carriers to fill profitably the ship (Haralambides 2019). Carriers have responded by rationalizing their services through vessel sharing agreements and/or strategic alliances, to facilitate the more efficient matching of supply to demand. However, such cooperation among carriers could be seen by some as anticompetitive, its effects not much different from those of liner conferences.

Figures 1, 2, 3 and 4 display quarter-over-quarter (QoQ) growth rates of containership capacity (measured in deadweight tons - dwt) and containerized imports to the United States, as well as the growth rate differentials for the Westbound Transatlantic (WTA); Eastbound Transpacific (ETP); and total US containerized import market. The data extends from the first quarter of 1998 to the last quarter of 2016. Capacity data is limited to fully cellular vessels only, ${ }^{2}$ obtained from the US Army Corp of Engineers (USACE) Vessel Clearance database. Trade volumes were taken from US Census

The WTA reveals a weak correlation (0.14) between capacity growth and containerized import growth. This mismatch was particularly wide in the period of a misplaced shipping investment euphoria, beginning in early 2006 and lasting to early 2008 (Haralambides and Thanopoulou 2014). Oppositely, following the disastrous year 2009, a recovery in trade, starting in the second quarter of 2010, appears to have surprised carriers whose capacity response was clearly insufficient. Adjusting supply to demand growth improved in 2011 but still remained insufficient.

More important than demand-supply correlations, however, at least in the special case of this paper, are the grown rate differentials and their persistence over time. The growth rate differentials, or what will be called henceforth the 'gap series' ${ }^{3}$ between shipping capacity and trade demand are displayed in Fig. 2.

Figure 2 shows a relatively narrow gap series up to 2005. As said above, a significant widening occurs in 2006 and lasts through to 2015. After this, a pattern more similar to the earlier part of the series is reestablished. Supply and demand in the ETP market is shown in Figs. 3 and 4.

Carriers serving the ETP appear to have more successfully anticipated future trade volumes than their counterparts in the WTA. The correlation coefficient between ETP slot capacity and demand growth was 0.51 , i.e., 3.6 times larger than that of WTA. The difference in the two markets is particularly stark when considering the period of the

\footnotetext{
${ }^{2} \mathrm{~A}$ "fully cellular" containership is one that exclusively accommodates maritime containers, leaving no room for any other type of cargo.

${ }^{3}$ The gap series, defined as the growth rate of capacity less the growth rate of demand is an indicator of the magnitude of the supply/demand imbalance and its direction over time.
} 


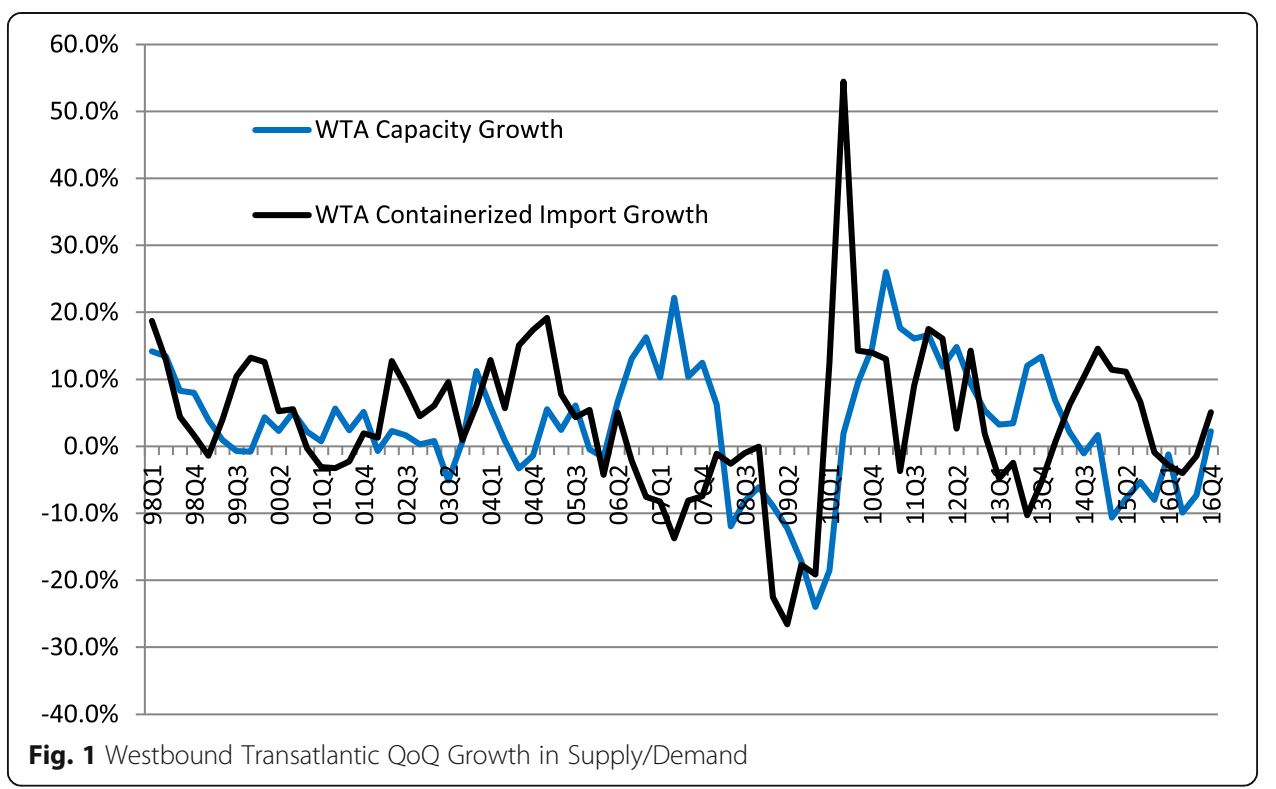

global financial crisis between 2007 and 2009. Whereas in the WTA there was significant divergence of supply and demand during this period, in the ETP the mismatch was far less, and the standard deviation of the 'gap series' indicated a relative stability of the capacity -demand divergence over time. One should note that small deviations suggest, on average, more fluid, or speedier, capacity adjustments, whereas large deviations indicate relative rigidities in capacity adjustments and therefore a longer persistence of excess capacity over time. The latter case is more pertinent to adaptive expectations, whereas in the former case, carriers are more likely to form rational expectations.

Figure 4 presents the gap series for the ETP. In general, positive gaps are capped at $0.10-0.20$ and negative gaps are above -0.20 except in two occasions. Clearly, carriers serving the ETP are more proficient in matching slot capacity to demand than their counterparts in the WTA. We attribute this to differing levels of competition in these two markets. Because the ETP is a more competitive market than the WTA, judging by the number of independent carriers operating there, ${ }^{4}$ errors in deployment can be more harmful to carriers' bottom line; a situation one might be tempted to see, perhaps with a degree of witticism, as a 'moral hazard' issue.

Table 1 presents the gap series statistics for the total sample WTA, pre- and postblock exemption, the total sample ETP and total US inbound trades.

For the full sample, the average difference between supply and demand growth was +0.002 in the WTA but -0.029 in the ETP and -0.002 for the total US market. The WTA reveals also a wider gap series variation, with a standard deviation of +0.135 compared to +.094 in the ETP and +.093 for the total US market. The interpretation of mean comparisons suggests that carriers in the WTA tend to overreact to demand growth compared to carriers serving the ETP and the total US market. At the same

\footnotetext{
${ }^{4}$ Based on data from MDS Transmodal (https://www.mdst.co.uk), a private maritime transport data provider and consulting firm in the UK, as of February 2019, carriers operating independently in the ETP accounted for $13 \%$ of the containership capacity in that market. In the WTA, independent carriers represented just $7 \%$ of containership capacity.
} 


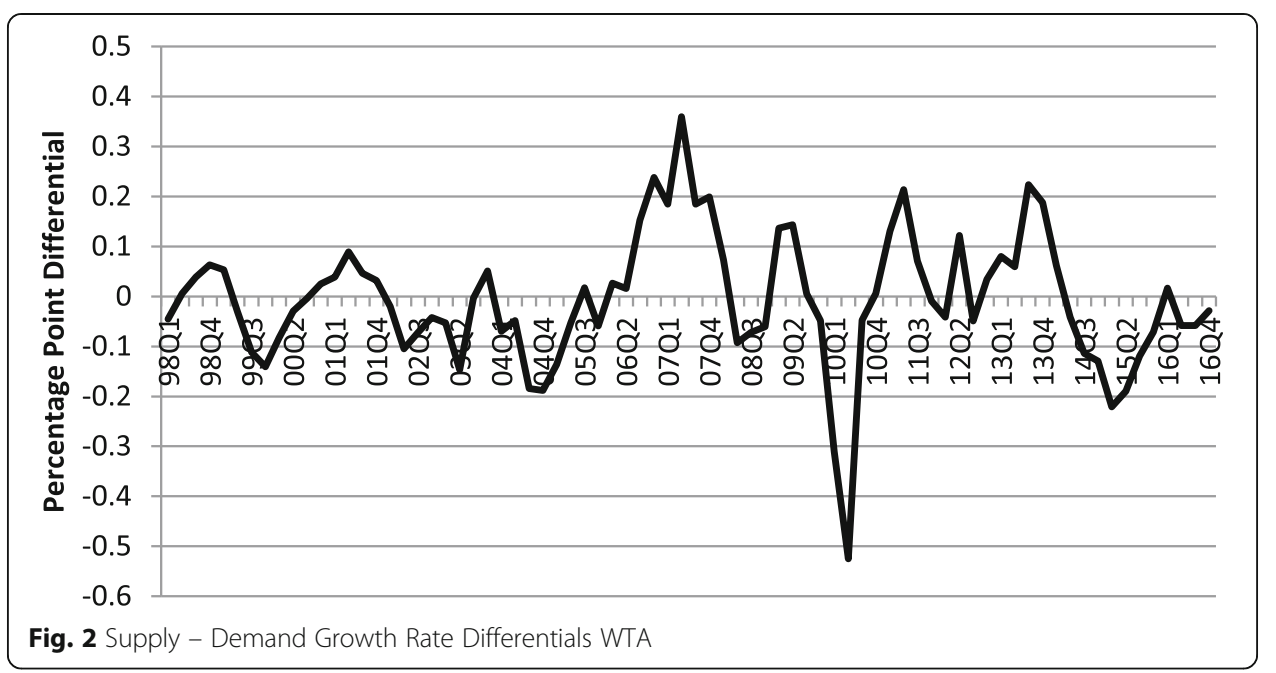

time, comparing the standard deviations, one might come to the conclusion that the supply/demand gap created by the WTA overreaction persisted for longer.

A difference can be detected in the WTA between the pre-and post-block exemption. WTA carriers tended to overreact to demand growth in the pre-block exemption period and underreact in the post-block exemption period. Again, one might be tempted to see this as a 'moral hazard' issue, associated to the 'protection' conference price-setting privileges were affording to carriers in the pre-block exemption period. However, gaps persisted for longer in the post-block exemption period, as evidenced by the higher standard deviation. Positive gaps were only slightly larger, on average, in the post-block exemption period, suggesting little to no change in carrier overreactions. Negative gaps, however, were almost four percentage points larger in absolute value during the post-exemption period compared to the pre-exemption period.

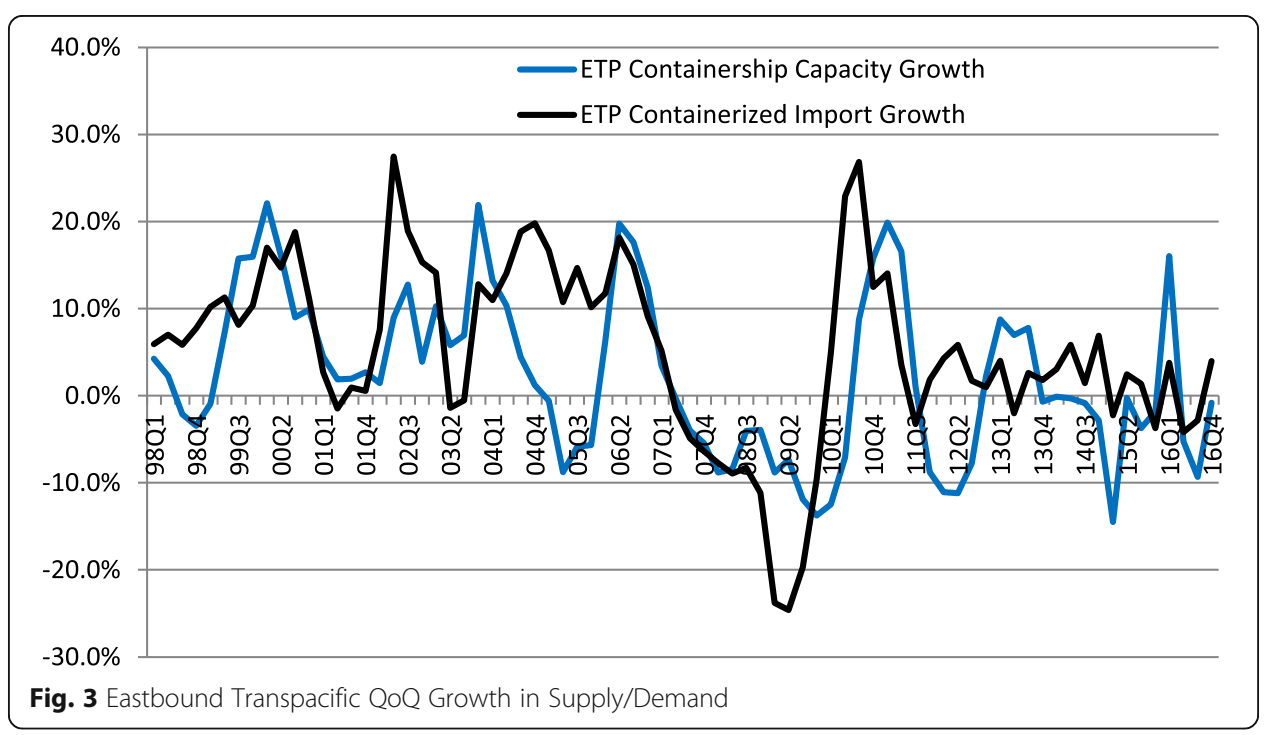




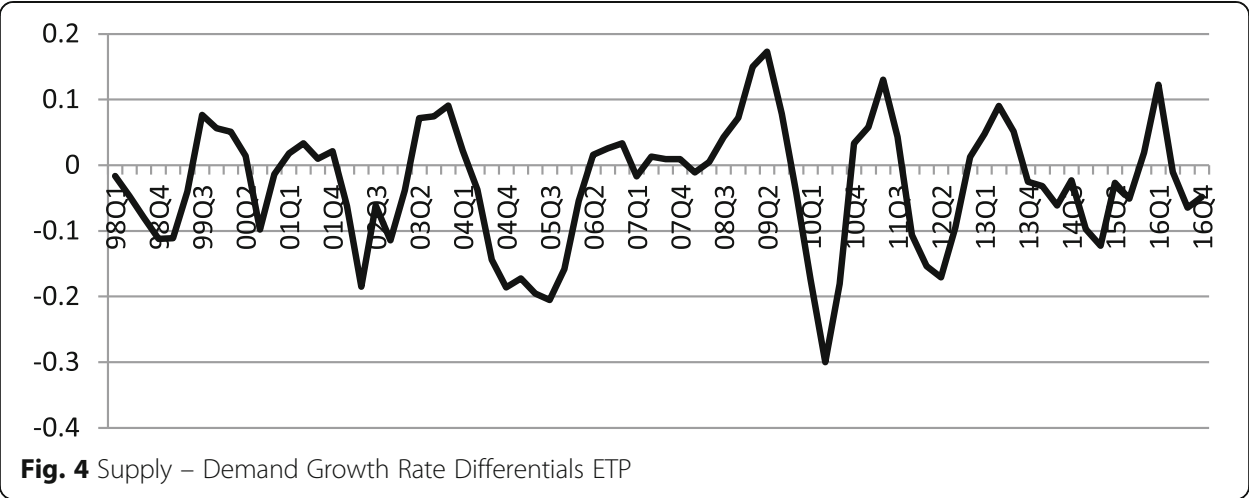

\section{Performance across regulatory regimes}

The data set is of sufficient length to allow us to compare supply/demand imbalances across different regulatory regimes in the WTA but not in the ETP where the Ocean Shipping Reform Act of 1999 would have been relevant. For the WTA, the task amounts to comparing carrier performance in efficiently meeting demand changes before and after the abolition (in 2008) of the EU Regulation 4056/86, which was granting antitrust immunity to price-fixing coalitions of carriers (better known as 'conferences'), serving the trades of the European Union. Descriptive statistics of carrier performance in meeting demand changes in the WTA are displayed in Table 2, and deviations there are those of Fig. 2.

Supply/demand gaps are on average wider in the post-abolition period (1.81 Slot Tons/Trade Tons) than in the pre-abolition one (1.52 Slot Tons/Trade Tons). In other words, the transportation of one ton of cargo in the post-abolition period necessitated $19 \%$ more shipping capacity (1.81/1.52) than before. Differently, one could argue that, in spite of the abolition and the ensuing tougher competition, excess capacity in the post-abolition period was considerably more prevalent. The standard deviation of the gap series also showed more variation in the post-abolition period.

In terms of the direction and strength of the relationship between the growth rate of demand and the growth rate of capacity, they tended to move in opposite directions in the pre-abolition period, but in the same direction post-abolition. This suggests a lag in carrier reaction to demand growth pre-abolition but an active stance post-abolition. In general, the above results show that carriers have performed better in matching supply to demand in the WTA during the pre-abolition period, when the market was dominated by 'self-regulating' and price-fixing conferences, than in the post-abolition period. ${ }^{5}$ But if supply-demand matching has worsened in the post-abolition period, it begs the question of whether carriers form expectations for trade growth differently under different regulatory regimes. What follows is an econometric exploration on how carriers form expectations for trade growth in both the WTA and ETP markets and, in the case of WTA, whether the formation of expectations differs from the pre- to the post abolition period.

${ }^{5}$ One is tempted to at least partially attribute worsening supply/demand matching, observed in the postabolition period, to the global financial crisis of 2008-09. However, should this be true, the same worsening should have been observed in the ETP where it did not. 
Table 1 "Gap series" statistics pre- and post block exemption

\begin{tabular}{|c|c|c|c|c|c|c|c|}
\hline \multirow[t]{2}{*}{ Sample } & \multirow[t]{2}{*}{ Count } & \multicolumn{2}{|l|}{ WTA } & \multicolumn{2}{|l|}{ ETP } & \multicolumn{2}{|c|}{ Total US } \\
\hline & & Mean & Std Dev & Mean & Standard Deviation & $\overline{\text { Mean }}$ & Standard Deviation \\
\hline Full Sample & $N=76$ & 0.002 & 0.135 & -0.029 & 0.094 & -0.002 & 0.093 \\
\hline Pre-Block Exemption & $N=43$ & 0.010 & 0.118 & & & & \\
\hline Post-Block Exemption & $N=33$ & -0.009 & 0.156 & & & & \\
\hline Positive Gaps & $N=76$ & 0.102 & 0.050 & 0.035 & 0.050 & 0.043 & 0.083 \\
\hline Pre-Block Exemption & $N=43$ & 0.097 & 0.005 & & & & \\
\hline Post-Block Exemption & $N=33$ & 0.108 & 0.012 & & & & \\
\hline Negative Gaps & $N=76$ & -0.098 & 0.095 & -0.094 & 0.069 & -0.067 & 0.059 \\
\hline Pre-Block Exemption & $N=43$ & -0.081 & -0.204 & & & & \\
\hline Post-Block Exemption & $N=33$ & -0.119 & -0.523 & & & & \\
\hline
\end{tabular}

Source: USACE, Authors' Calculations

\section{Expectations models}

In this section, we develop and estimate models of containership operating capacity, in an attempt to determine if carrier capacity decisions are a consequence of adaptive expectations or if, instead, carriers exhibit rational expectations in their choices. Previous works on expectations in shipping provide zero guidance, since these are directed at bulk and tanker shipping, both entirely different markets than fixed-schedule liner shipping markets. ${ }^{6}$

To begin, we note that the analysis presented here concerns only short-term adjustments to supply/demand imbalances. This is starkly different from the long-term investment behavior in container shipping, where capacity adjustments derive from investment in new vessels, or from acquiring or merging with rival firms (For the stages of short- and long-term adjustment of shipping supply see Haralambides 2019; Koopmans 1939).

\section{Adaptive expectations}

Adaptive expectations are formulated when economic agents observe past values of a certain variable, and then use those values to generate forecasts (of that variable). Agents are assumed to accomplish this mechanically, ignoring any other, current, information that might have had an impact on the variable in question. For instance, should demand rise over a relevant historical time period, carriers with adaptive expectations would normally expect the same thing to happen going forward. Such a mechanical process in the formation of expectations leaves carriers vulnerable to perhaps being fooled into thinking that an earlier rate of demand growth would continue, when in fact it might not. This may lead to a stable increase in capacity, even if it results in persistent overcapacity. Thus, this form of expectations can generate inertia in key decision variables, as errors in projections can persist in practical terms for more than one forecast period ahead. In our case, the key decision variable is (container shipping) capacity and, for optimal operations, it must closely match containerized trade volume. A reasonable representation of adaptive expectations can be written as in Eq. (1).

${ }^{6}$ Beenstock and Vergottis (1987) simply assume rational expectations for the bulk and tanker markets while Binkley and Bessler (1983) find support for "elastic expectations", which they explain as an immoderate response to demand signals. 
Table 2 Capacity deployed (DWT) relative to demand (trade volume) in the WTA pre- and postantitrust block exemption

\begin{tabular}{lll}
\hline Westbound Transatlantic Market & $\begin{array}{l}\text { Pre- (97Q1 - } \\
\text { 08Q3) }\end{array}$ & $\begin{array}{l}\text { Post (08Q4 - } \\
16 \mathrm{Q} 4)\end{array}$ \\
\hline Ratio of Supply/Demand (Slot Capacity in DW Tons/Containerized Trade) & 1.52 & 1.81 \\
$\begin{array}{l}\text { Standard Deviation Slot Capacity - Containerized Trade Growth Rate } \\
\text { Differential }\end{array}$ & $0.118(\mathrm{~N}=43)$ & $0.156(\mathrm{~N}=33)$ \\
Capacity - Containerized Trade Growth Rate Correlation & -0.29 & +0.31 \\
\hline
\end{tabular}

Source: USACE and author's calculations

$$
v_{t}^{e}=v_{t-1}^{e}+\beta\left(v_{t}-v_{t-1}^{e}\right)
$$

where $v_{t}^{e}$ is the expected trade volume at time $t, v_{t-1}^{e}$ is the expectation of trade volume for time $t$ formed in in the previous period and $v_{t}$ is the actual trade volume at time $t$. For stability, $\beta$ must lie between 0 and 1 and can be interpreted as the fraction by which volume expectations adjust to past prediction errors per unit of time. The larger the $\beta$, the faster expectations adjust. If $\beta=0$, expectations never adjust, whereas if $\beta=1$, agents have perfect foresight, as would be the case with rational expectations.

Equation (1) can be expanded and rearranged to produce

$$
v_{t}^{e}=\beta v_{t}+(1-\beta) v_{t-1}^{e}
$$

Lagging (2) and solving iteratively generates a distributed lag with geometrically declining weights as in Eq. (3)

$$
v_{t}^{e}=\beta v_{t}+\beta(1-\beta) v_{t-1}+(1-\beta)^{2} v_{t-2}^{e}+\ldots+(1-\beta)^{n} v_{t-n}
$$

Equation (3) states that trade volume expectations for next period are a weighted average of past realizations; but as $\beta$ is assumed to lie between 0 and 1 , the weights decline geometrically with each historical realization. This implies that expectations in the distant past can be practically ignored since their impact on current expectations would be negligible. Evidence for adaptive expectations would amount to estimating Eq. (3) and testing for $0<\beta<1$.If $\beta=1$, the weights of past realizations go to zero and expected volume is equal to actual volume. The latter is equivalent to rational expectations, whereby economic agents are assumed to possess perfect foresight.

In practical terms, Eq. (3) cannot be estimated in its current specification since $v_{t}^{e}$ is unobservable. However, we do observe capacity, $k_{t}$, and because the theoretically optimum level of capacity utilization in the short-run is assumed to be $100 \%$, then in equilibrium $k_{t}=v_{t}^{e}$.

Taking logs of both sides of (1),

$$
\ln v_{t}^{e}=\ln v_{t-1}^{e}+\beta\left(\ln v_{t}-\ln v_{t-1}^{e}\right)
$$

and invoking the equilibrium condition $k_{t}=v_{t}^{e}$, while acknowledging the seasonal nature of the liner shipping industry, ${ }^{7}$ we have

\footnotetext{
${ }^{7}$ The seasonality of demand in liner shipping markets is easily observed. "Backwards looking" carriers are therefore assumed to base their decisions not on the immediate past quarter but on the same quarter oneyear earlier.
} 


$$
\ln k_{t}=\ln k_{t-4}+\beta\left(\ln v_{t}-\ln k_{t-4}\right)
$$

Capacity then depends on capacity deployed in the same quarter of the previous year, with some correction for supply/demand imbalance. Equation (5) can be rearranged to produce

$$
\ln k_{t}=\beta \ln v_{t}+(1-\beta) \ln k_{t-4}
$$

If carriers rely on past values of capacity, then $\beta<1$ and expectations are described as adaptive. However, if $\beta=1$, this is evidence against adaptive expectations since such a coefficient indicates that past realizations are ignored.

\section{Rational expectations}

Adaptive expectations imply that the structural parameters governing economic choices are static, meaning that decisions agents make today are based on quantitative relationships between key variables observed and established in the past. Beginning with Muth (1961), economists began to question adaptive expectations on the grounds that such formulations are too mechanical in nature, ignoring critical current information in favor of established principles. Muth (1961) pointed out the non-optimality of this behavior and proposed an alternative he called rational expectations. Here, agents make use of all available information and not just past relationships. Among others, this would imply that the expected value of some target variable, such as price or demand, will be an unbiased predictor of the actual realization.

Rational expectations can be represented by the expression $X_{t}=\beta X_{t}^{e}+e_{t}$, where $X_{t}$ is the actual realization of the target variable at time $t$ and $X_{t}^{e}$ is its expected value at time $t$ but formulated in a prior period. The error term $e_{t}$ is assumed to be distributed normally with zero mean and constant variance. If $\beta=1$, the agent is said to formulate expectations rationally, unhindered by strict adherence to observations of past realizations; instead they make projections governed by all available information.

Testing for rational expectations has primarily relied upon comparing survey data on expectations to actual realizations. A recent example is from Puah et al. (2013) who examined the rational expectations hypothesis in Malaysian manufacturing industries. However, according to prior studies (Lovell 1986; Svendsen 1993), evidence for rational expectations collected from such "direct" tests is weak.

"Indirect" tests of the rational expectations hypothesis are an alternative, whenever -as in the case of liner shipping- survey data is unavailable. For example, a liner shipping firm's model aiming to predict trade volume $\left(v_{t}\right)$ could conceivably look as in Eq. (7) below.

$$
v_{t}=\alpha_{0}+\alpha_{1} v_{t-1}+X \beta+u_{t}
$$

where $X$ is a matrix of explanatory variables that could include a measure of global trade, the real exchange rate, etc., and $u$ is an error term of zero mean. To add the perfect foresight condition, consistent with rational expectations, we take expected values of (7) to get

$$
E\left(v_{t}\right)=\alpha_{0}+\alpha_{1} v_{t-1}+X \beta+E\left(u_{t}\right)
$$

If $E\left(u_{t}\right)=0$, it is straightforward to show (subtract (8) from (7)) that 


$$
v_{t}-E\left(v_{t}\right)=0
$$

which is the same as $\beta=1$ in Eq. (6).

Again, $E\left(v_{t}\right)$ is unobserved but it can be approximated by $k_{t}$ as long as the assumption of optimal capacity utilization equaling $100 \%$ holds. Testing for rational expectations is therefore a matter of testing for $\beta=1$, and that the forecast errors in Eq. (5) are zero. These two conditions imply that capacity choices are made with perfect foresight and as such they are unbiased. In this case, the unbiased forecast is consistent with rational expectations ${ }^{8}$ and we can therefore rely on the results of Eq. (6) to test for rational expectations.

\section{The island model}

The perfect foresight assumption is fairly restrictive and unlikely to hold in markets with wide fluctuations in demand. We therefore undertake to construct two alternative tests that relax this assumption. The first test derives from what has come to be known as the 'Lucas Critique' (Lucas Jr. 1972). In short, Lucas argued that firms' output in imperfectly competitive markets responds inversely to variations in aggregate demand but positively to its own, firm-specific, demand. Lucas arrived to this conclusion via the famous "Island Model" where firms must decide whether changes in aggregate demand are firm-specific, in which case output responds positively, or are changes explained by general economic trends, in which case output does not respond.

A critical determinant of this decision is the firm's observance of historic variations in the relative price of its own output, together with those of the aggregate price level. If historical aggregate demand varies more, relative to firm-specific demand, the individual firm will be more likely to attribute changes in its own price to changes in aggregate demand, rather than to the demand for its own output. In this case, its price relative to the aggregate price will be stable and will be sufficient to maintain some constant profit. On the other hand, should the firm decide that variation in demand for its own output is higher relative to aggregate demand, the firm is more likely to respond with a price change larger than the change in the aggregate price level. ${ }^{9}$ Should this be the case, expectations can be characterized as rational since the firm will dismiss developments in overall demand in favor of using the most relevant information.

The Lucas Critique would suggest that liner shipping operators must distinguish between demand for their own containerized services from overall demand for trade. In this case, a specification such as in Eq. 10 below would be reasonable.

$$
k_{t}=\alpha_{0}+\alpha_{1} v_{t}+\alpha_{2} \tilde{y}_{t}+\alpha_{3} \tilde{y}_{t-1}+a_{4} c_{t}+u_{t}
$$

where $v_{t}$ is liner market level import demand at time $t, \widetilde{y}_{t}$ is the growth rate of aggregate import demand at time $t$ and $c_{t}$ represents a measure of carrier costs. This specification roughly follows Lynde (1990) who used a similar model to examine the formation of expectations across several US manufacturing industries. The most

\footnotetext{
${ }^{8}$ This is equivalent to saying that $\beta=1$ in Eq. (6).

${ }^{9}$ One issue that could cause concern in applying the Lucas Critique to liner shipping is the question of market structure. Lucas' theory was directed at imperfectly competitive markets, so that a clear distinction could be made between increases in aggregate demand and in firm-specific demand, implying that firms produce and sell differentiated products. While containerized shipping can be characterized at first glance as an industry offering a homogenous good, on closer inspection there are opportunities for product differentiation via such attributes as door-to-door services and integrated logistics (Haralambides 2019).
} 
definitive results supporting rational expectations in liner shipping are when $\alpha_{1}=1$ and $\alpha_{2}=0$.In other words, as is postulated by the rational expectations school, agents cannot be fooled by changes in aggregate demand. The results of estimating the Lucas Model are given in Table 5 (OLS) and Table 6 (GMM).

\section{Forward looking model}

The last test we run, as outlined and conducted by Fair (1993), is an application of the idea that firms with rational expectations are "forward looking", meaning they make current decisions on pricing and other key variables, based partially on what they expect the future will hold. This stands in direct contrast to adaptive expectations, in which firms are strictly backward looking. The forward looking model, therefore, necessitates the inclusion of leads as well as lags in an econometric specification. A reasonable model could be as in Eq. (11):

$$
k_{t}=\alpha_{0}+\alpha_{1} v_{t+i}+\alpha_{2} v_{t-i}+u_{t}
$$

Where $v_{t+i}$ is containerized trade volume $i$ periods ahead. If firms are forward looking then $\alpha_{1}$ will be significant but $\alpha_{2}$ will be 0 . Given the inherent seasonality in liner shipping, we chose $i=4$ (our data is quarterly) for both the lead and the lagged variables. Our results are presented in Table 6.

\section{Data and market definitions}

Quarterly demand data from 1997 to 2016 were obtained from US Census' "USA Trade Online". The data includes total trade volume; total containerized trade volume; total trade value and total containerized trade value; commodity; country of origin; and US port of entry. On the supply side, the US Army Corp of Engineers collects vessel clearance data that includes the port of entry, the individual vessel (including her IMO number) and the country of origin. Vessel capacity in TEUs and in deadweight tons was obtained by matching the vessel's IMO number to vessel characteristics found in various internet websites (most were collected from www.containership-info.net and www.vesseltracker.net).

In addition to the aggregate US inbound container shipping market, we consider the ETP and the WTA markets individually. The ETP involves the aggregate containerized imports and container-carrying-capacity from the countries/ports of Northeast and Southeast Asia to the US west coast. The WTA is an aggregate of containerized shipments from Europe, including Russia and the Mediterranean, to the US east- and gulf coasts. One caveat in the capacity data is the treatment of Canadian transshipment: Some Atlantic services call the Canadian ports of Halifax and Montreal, subsequently serving US demand via truck or intermodal rail. This volume is not captured as waterborne trade from Europe but from Canada. Moreover, it is only when the vessel makes a secondary call at a US port that it can be included in the dataset. The same scenario plays out in the transpacific trade through Vancouver and increasingly Port Prince Rupert. Since this trade is invisible to current data sources, we have chosen to ignore it as insubstantial relative to trade moving directly through US ports.

Carrier operating costs are represented by real fuel costs obtained from the US Energy Information Agency. Shocks are represented by a 0-1 dummy variable to control for the events of September 11, 2001 ( 1 for quarter 4 in 2001; quarter 1 in 2002 and 0 
otherwise) and the global financial crisis (1 for the quarters between 08Q1 and 09Q4, and 0 otherwise.)

\section{Results and discussion}

The adaptive expectations model is represented in estimable form by Eq. (6). As it includes a lagged dependent variable, estimates of this model by ordinary least squares is problematic. We therefore present two estimates. In the first, we establish the independence of the error term and the lagged endogenous variable by the condition that if errors are serially uncorrelated then they are also uncorrelated with the lagged endogenous variable. We establish this by estimating the equation in first differences and using the Breusch-Godfrey test to confirm the absence of serial correlation in the errors. The results for the full sample and the pre- and post- Block Exemption ${ }^{10}$ samples for the WTA are shown in Table 3, with t-statistics given in parentheses. The second set of estimates is generated using a two-step, generalized method of moments (GMM) estimator, detailed by Hansen (1982). Hanson's estimator consists of generating a weighting matrix that is the inverse of the covariance matrix in the first step regression, then using them to weight the estimates in the second step. This method controls for possible heteroscedasticity.

The first differences (OLS) model for the full sample suggests that carrier capacity responses in the ETP are much more elastic $(+0.604)$ to changes in trade volume than in the WTA $(+0.067)$ and the total US market (+ 0.305). As the elasticities of capacity adjustments with respect to current trade volume in both the ETP and the WTA are less than unity, the results indicate that carrier expectations are adaptive rather than rational. In the WTA, carrier responses are of the incorrect sign and are insignificant during the pre-block exemption period. That changes in the post-block exemption period $(+0.232)$ but not enough to confidently say that the way in which expectations are formed has changed. Table 4 contains the results of estimating the same model as Table 3 but with Hanson's two-step GMM process rather than OLS.

The results are generally consistent with those in Table 2, albeit with more explanatory power. The coefficients of trade volume are each different from 1, indicating adaptive expectations in all markets. Comparing the WTA pre- and post-block exemption, $\boldsymbol{\beta}$ rises significantly between samples but not sufficiently to change the conclusion of adaptive expectations for both periods.

To determine whether rational expectations play a role in the formation of carrier expectations we estimated the Island Model, represented in Eq. (10). The results are given in Table 5. Note that the growth rate of total US import demand and containerized imports demand enter the equation as four-quarter moving averages.

Each variable is differenced one period but none performs particularly well. Looking at the coefficient of containerized imports $\left(\alpha_{1}\right)$ relative to that of total imports $\left(\alpha_{2}\right)$, the results for the full sample indicate that, along with the total market, carriers in the ETP are less likely to be misled by changes in overall US import growth but are instead motivated by changes in their own market or "island". WTA carriers exhibit similar behavior in the total sample but results in the separate samples indicate the opposite.

\footnotetext{
${ }^{10}$ Pre-block exemption is the period between 1997 and the second quarter of 2008 when the European Commission (Directorate General for Competition) scrapped Regulation 4056/86 that was granting antitrust immunity to liner shipping conferences. The post-block exemption period is defined as all subsequent quarters.
} 
Table 3 Adaptive expectations - OLS estimates - equation in first differences

\begin{tabular}{|c|c|c|c|c|c|c|c|c|}
\hline Series & Constant & $V_{t}$ & $K_{t-4}$ & Shocks & $\begin{array}{l}\text { Wald } \\
\text { Test }\end{array}$ & $\begin{array}{l}\text { Breusch - } \\
\text { Godfrey }\end{array}$ & $\begin{array}{l}\text { Adj R- } \\
\text { Squared }\end{array}$ & F-Statistic \\
\hline \multicolumn{9}{|c|}{ Full Sample $N=75$} \\
\hline All Trades & $\begin{array}{l}0.002 \\
(0.044)\end{array}$ & $\begin{array}{l}0.305^{c} \\
(3.99)\end{array}$ & $\begin{array}{l}0.470^{c} \\
(5.20)\end{array}$ & $\begin{array}{l}-0.0003 \\
(-0.020)\end{array}$ & $82.3^{c}$ & $0.024(\operatorname{Pr}=0.876)$ & 0.58 & $35.06^{c}$ \\
\hline ETP & $\begin{array}{l}-0.001 \\
(-0.26)\end{array}$ & $\begin{array}{l}0.604^{c} \\
(8.17)\end{array}$ & $\begin{array}{l}0.151^{\mathrm{a}} \\
(1.75)\end{array}$ & $\begin{array}{l}-0.007 \\
(-0.43)\end{array}$ & $50.4^{c}$ & $0.010 \mathrm{Pr}=0.9194$ & 0.67 & $52.08^{c}$ \\
\hline WTA & $\begin{array}{l}0.008 \\
(1.14)\end{array}$ & $\begin{array}{l}0.067 \\
(1.06)\end{array}$ & $\begin{array}{l}0.421^{c} \\
(4.07)\end{array}$ & $\begin{array}{l}-0.037^{b} \\
(-2.03)\end{array}$ & $168.3^{c}$ & $.0901(\operatorname{Pr}=0.764)$ & 0.22 & $8.03^{c}$ \\
\hline \multicolumn{9}{|c|}{ Pre-Block Exemption (WTA, $N=41)$} \\
\hline WTA & $\begin{array}{l}0.006 \\
(0.66)\end{array}$ & $\begin{array}{l}-0.021 \\
(-0.27)\end{array}$ & $0.422^{b}(2.98)$ & $\begin{array}{l}-0.041 \\
(-1.49)\end{array}$ & $167.6^{c}$ & $0.002(\operatorname{Pr}=0.967)$ & 0.16 & $3.45^{\mathrm{b}}$ \\
\hline \multicolumn{9}{|c|}{ Post-Block Exemption (WTA, N = 29) } \\
\hline WTA & $\begin{array}{l}0.010 \\
(0.88)\end{array}$ & $\begin{array}{l}0.232 \\
(1.84)^{a}\end{array}$ & $0.371(2.19)^{\mathrm{b}}$ & $\begin{array}{l}-0.060 \\
(-0.99)\end{array}$ & $37.12^{c}$ & $0.209(\operatorname{Pr}=0.647)$ & 0.22 & $3.65^{\mathrm{b}}$ \\
\hline
\end{tabular}

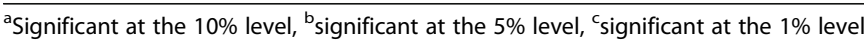

Moreover, $\alpha_{1}$ is statistically significant only for the total sample. These results provide some support for rational expectations in the ETP but not in the WTA.

The same Island Model, estimated using Hanson's two-step GMM, is given in Table 6. The results are generally consistent with those obtained from OLS.

Finally, we estimate a variation of Fair's forward looking model of Eq. (11), estimated by Hanson's two-step GMM. The results are posted in Table 7.

Looking specifically at the coefficients estimated on the four-quarter lead variable, the results in Table 7 indicate forward looking and therefore rational expectations on the part of carriers in the ETP. In the overall market and in the WTA specifically, no such evidence is revealed.

\section{Conclusion}

Our results suggest that expectations that drive decisions on capacity deployment among liner shipping companies are formed adaptively in the overall US liner shipping

Table 4 Adaptive expectations - GMM

\begin{tabular}{|c|c|c|c|c|c|c|c|}
\hline Series & Constant & $V_{t}$ & $K_{t-4}$ & Shocks & $\begin{array}{l}\text { Wald Test } \\
(\beta=1)\end{array}$ & $\begin{array}{l}\text { Centered R- } \\
\text { Squared }\end{array}$ & F-Statistic \\
\hline \multicolumn{8}{|c|}{ Full Sample $N=75$} \\
\hline All Trades & $0.131(0.25)$ & $0.134^{\mathrm{a}}(1.78)$ & $0.856^{c}(11.35)$ & $\begin{array}{l}-0.033 \\
(-1.58)\end{array}$ & $132.0^{c}$ & 0.97 & $334.6^{c}$ \\
\hline ETP & $7.337^{c}(3.50)$ & $0.336^{\mathrm{b}}(2.44)$ & $0.267(1.15)$ & $\begin{array}{l}0.004 \\
(0.09)\end{array}$ & $23.4^{c}$ & 0.75 & $28.5^{c}$ \\
\hline WTA & $1.358(0.99)$ & $0.190(1.57)$ & $0.740^{\complement}(7.27)$ & $\begin{array}{l}-.081^{\mathrm{b}} \\
(-1.94)\end{array}$ & $45.1^{c}$ & 0.82 & $46.3^{c}$ \\
\hline \multicolumn{8}{|c|}{ Pre-Block Exemption (WTA, N = 41) } \\
\hline WTA & $-0.606(-0.32)$ & $-0.078(-0.59)$ & $1.115^{\mathrm{c}}(6.49)$ & $\begin{array}{l}-0.076^{a} \\
(-1.74)\end{array}$ & $66.4^{c}$ & 0.74 & $23.8^{c}$ \\
\hline \multicolumn{8}{|c|}{ Post-Block Exemption (WTA, N = 29) } \\
\hline WTA & $4.931^{\mathrm{a}}(1.72)$ & $0.331(1.37)$ & $0.392^{b}(1.96)$ & $\begin{array}{l}-0.214^{b} \\
(-2.16)\end{array}$ & $7.7^{b}$ & 0.65 & $8.66^{\mathrm{c}}$ \\
\hline
\end{tabular}

${ }^{\mathrm{a}}$ Significant at the $10 \%$ level, ${ }^{\mathrm{b}}$ significant at the $5 \%$ level, ${ }^{\mathrm{C}}$ significant at the $1 \%$ level 
Table 5 Rational Expectations island model: OLS in first differences

\begin{tabular}{|c|c|c|c|c|c|c|c|c|}
\hline Series & Constant & $\begin{array}{l}\text { Growth Rate } \\
\text { Market Level } \\
\text { Import Volume }\end{array}$ & $\begin{array}{l}\text { Growth Rate } \\
\text { Total Import } \\
\text { Value }\end{array}$ & $\begin{array}{l}\text { Real Price } \\
\text { Bunker } \\
\text { Fuel }\end{array}$ & Shocks & $\begin{array}{l}\text { Breusch - } \\
\text { Godfrey }\end{array}$ & $\begin{array}{l}\text { Adj R- } \\
\text { Squared }\end{array}$ & $\begin{array}{l}\text { F- } \\
\text { Statistic }\end{array}$ \\
\hline \multicolumn{9}{|c|}{ Full Sample $N=72$} \\
\hline $\begin{array}{l}\text { All } \\
\text { Trades }\end{array}$ & $0.001(0.18)$ & $0.534^{\mathrm{b}}(2.47)$ & $\begin{array}{l}-0.151 \\
(-0.85)\end{array}$ & $\begin{array}{l}-0.005(- \\
0.20)\end{array}$ & $\begin{array}{l}-0.002 \\
(-.01)\end{array}$ & $\begin{array}{l}0.072(\operatorname{Pr}= \\
0.788)\end{array}$ & 0.04 & 1.77 \\
\hline ETP & $\begin{array}{l}-0.0009(- \\
0.11)\end{array}$ & $1.341^{\mathrm{c}}(4.75)$ & $\begin{array}{l}-0.352 \\
(-1.49)\end{array}$ & $0.017(0.53)$ & $\begin{array}{l}0.005 \\
(0.21)\end{array}$ & $\begin{array}{l}0.200(\operatorname{Pr}= \\
0.655)\end{array}$ & 0.11 & $3.41^{\mathrm{b}}$ \\
\hline WTA & $0.003(0.37)$ & $0.361^{\mathrm{a}}(1.74)$ & $\begin{array}{l}0.087 \\
(0.38)\end{array}$ & $0.005(0.14)$ & $\begin{array}{l}-0.031 \\
(-1.39)\end{array}$ & $\begin{array}{l}1.308(\operatorname{Pr}= \\
0.252)\end{array}$ & 0.12 & $3.49^{\mathrm{a}}$ \\
\hline \multicolumn{9}{|c|}{ Pre-Block Exemption (WTA, $N=38$ ) } \\
\hline WTA & $0.005(0.47)$ & $-0.440(-1.06)$ & $\begin{array}{l}-0.897^{b} \\
(-2.50)\end{array}$ & $\begin{array}{l}-0.036(- \\
0.42)\end{array}$ & $\begin{array}{l}-0.070^{b} \\
(-2.00)\end{array}$ & $\begin{array}{l}4.337(\operatorname{Pr}= \\
0.037)\end{array}$ & 0.16 & $2.73^{b}$ \\
\hline \multicolumn{9}{|c|}{ Post-Block Exemption (WTA, N = 33) } \\
\hline WTA & $0.004(0.40)$ & $0.347(1.48)$ & $\begin{array}{l}0.522^{\mathrm{a}} \\
(1.86)\end{array}$ & $0.023(0.69)$ & $\begin{array}{l}0.016 \\
(0.49)\end{array}$ & $\begin{array}{l}0.739(\operatorname{Pr}= \\
0.390)\end{array}$ & 0.31 & $4.59^{\mathrm{b}}$ \\
\hline
\end{tabular}

${ }^{\mathrm{a}}$ Significant at the $10 \%$ level, ${ }^{\mathrm{b}}$ significant at the $5 \%$ level, ${ }^{\mathrm{C}}$ significant at the $1 \%$ level

market and in the individual markets of the WTA as well as, to a lesser degree, in the ETP. In the ETP, long considered to be a more competitive market than the WTA, there is some support for rational expectations, as carriers tend to adjust capacity more fluidly than in the WTA. While the support offered in the models is not sufficiently convincing to make a more definitive statement, our results support the statement that adjustments in capacity are more rapid in the ETP than in the WTA. Further, and specific to the WTA, the abolition of antitrust immunity did nothing to change the way expectations are formed. Indeed, the models show that WTA carriers are even slower to adjust their capacity to demand fluctuations in the post-block exemption period than they were in the pre-block exemption one. The obvious question is why? We see two reasons. First, the difference may be attributed to increased levels of uncertainty in the post-abolition period, that have made carriers reluctant to commit investment in new capacity, or to remove existing capacity. Second, and perhaps more importantly, while conferences were abolished in Europe in 2008, global alliances and industry

Table 6 Rational expectations island model: GMM

\begin{tabular}{|c|c|c|c|c|c|c|c|}
\hline Series & Constant & $\begin{array}{l}\text { Growth Rate } \\
\text { Market Level } \\
\text { Import Volume }\end{array}$ & $\begin{array}{l}\text { Growth Rate } \\
\text { Total Import } \\
\text { Value }\end{array}$ & $\begin{array}{l}\text { Real Price } \\
\text { Bunker Fuel }\end{array}$ & Shocks & $\begin{array}{l}\text { Adj R- } \\
\text { Squared }\end{array}$ & F-Statistic \\
\hline \multicolumn{8}{|c|}{ Full Sample $N=72$} \\
\hline All Trades & $0.040^{\mathrm{a}}(1.72)$ & $0.361^{\mathrm{a}}(1.81)$ & $-0.073(-0.56)$ & $\begin{array}{l}-0.006 \\
(-0.49)\end{array}$ & $\begin{array}{l}-0.003 \\
(-.091)\end{array}$ & 0.16 & 2.23 \\
\hline ETP & $0.022(0.62)$ & $0.678^{\mathrm{b}}(2.56)$ & $-0.126(-0.60)$ & $\begin{array}{l}-0.020 \\
(-1.00)\end{array}$ & $\begin{array}{l}0.006 \\
(0.14)\end{array}$ & 0.44 & $5.37^{c}$ \\
\hline WTA & $-0.016(-0.56)$ & $0.247(1.24)$ & $0.332^{b}(1.96)$ & $\begin{array}{l}0.030 \\
(1.59)\end{array}$ & $\begin{array}{l}-0.088^{b} \\
(-2.40)\end{array}$ & 0.41 & $6.26^{c}$ \\
\hline \multicolumn{8}{|c|}{ Pre-Block Exemption (WTA, $N=38$ ) } \\
\hline WTA & $0.039(0.92)$ & $-0.068(-0.26)$ & $-0.221(-0.95)$ & $\begin{array}{l}0.033 \\
(-0.80)\end{array}$ & $\begin{array}{l}-0.084^{b} \\
(-2.05)\end{array}$ & 0.19 & 1.01 \\
\hline \multicolumn{8}{|c|}{ Post-Block Exemption (WTA, N = 33) } \\
\hline WTA & $-0.100^{b}(-2.20)$ & $0.197(0.71)$ & $0.449^{b}(2.08)$ & $\begin{array}{l}0.067^{c} \\
(3.22)\end{array}$ & $\begin{array}{l}-0.087^{a} \\
(-1.74)\end{array}$ & 0.83 & $21.66^{c}$ \\
\hline
\end{tabular}

${ }^{\mathrm{a}}$ Significant at the $10 \%$ level, ${ }^{\mathrm{b}}$ significant at the $5 \%$ level, ${ }^{\mathrm{C}}$ significant at the $1 \%$ level 
Table 7 Rational expectations forwards looking fair model: GMM

\begin{tabular}{|c|c|c|c|c|c|c|c|}
\hline Series & Constant & $\begin{array}{l}\text { Trade Volume 4- } \\
\text { Quarter Lead }\end{array}$ & $\begin{array}{l}\text { Trade Volume 4- } \\
\text { Quarter Lag }\end{array}$ & $\begin{array}{l}\text { Real Price } \\
\text { Bunker Fuel }\end{array}$ & Shocks & $\begin{array}{l}\text { Adj R- } \\
\text { Squared }\end{array}$ & F-Statistic \\
\hline \multicolumn{8}{|c|}{ Full Sample $N=71$} \\
\hline All Trades & $5.101^{\mathrm{b}}(2.28)$ & $-0.016(-0.03)$ & $0.687^{\mathrm{a}}(1.61)$ & $\begin{array}{l}0.106^{\mathrm{C}} \\
(2.85)\end{array}$ & $\begin{array}{l}-0.084 \\
(-0.083)\end{array}$ & 0.89 & $57.6^{\mathrm{C}}$ \\
\hline ETP & $4.086(1.52)$ & $1.283^{\mathrm{C}}(2.98)$ & $-0.467(-1.30)$ & $\begin{array}{l}-0.014 \\
(-0.23)\end{array}$ & $\begin{array}{l}0.218^{c} \\
(2.10)\end{array}$ & 0.35 & $10.0^{c}$ \\
\hline WTA & $4.745(1.24)$ & $0.128(0.29)$ & $0.625^{\mathrm{b}}(2.19)$ & $\begin{array}{l}0.126^{c} \\
(3.38)\end{array}$ & $\begin{array}{l}-0.031 \\
(-0.34)\end{array}$ & 0.72 & $23.7^{c}$ \\
\hline \multicolumn{8}{|c|}{ Pre-Block Exemption (WTA, $N=37$ ) } \\
\hline WTA & $15.361^{c}(4.56)$ & $0.261(0.59)$ & $-0.194(-0.35)$ & $\begin{array}{l}0.237^{b} \\
(2.22)\end{array}$ & $\begin{array}{l}0.037 \\
(0.62)\end{array}$ & 0.59 & $8.58^{c}$ \\
\hline \multicolumn{8}{|c|}{ Post-Block Exemption (WTA, $N=25$ ) } \\
\hline WTA & $0.508(0.04)$ & $0.053(0.04)$ & $0.977^{\mathrm{b}}(1.93)$ & $\begin{array}{l}0.067 \\
(0.95)\end{array}$ & $\begin{array}{l}-0.289 \\
(-1.04)\end{array}$ & 0.79 & $18.8^{c}$ \\
\hline
\end{tabular}

${ }^{\mathrm{a}}$ Significant at the $10 \%$ level, ${ }^{\mathrm{b}}$ significant at the $5 \%$ level, ${ }^{\mathrm{c}}$ significant at the $1 \%$ level

consolidation were not. Thus, carriers were able to retain at least some insulation from competition and therefore had little cause to change their expectations behavior. If one believes that adaptive expectations are consistent with concentrated industries whereas rational expectations suggest more competition, then the results of this paper could suggest that the abolition of the liner conference system has failed to improve the level of competition in Europe - US liner shipping markets.

\section{Abbreviations}

DWT: Deadweight tons; ETP: Eastbound Transpacific; GMM: Generalized method of moments; OLS: Ordinary least squares; QoQ: Quarter-On-Quarter; USACE: United States Army Corp of Engineers; WTA: Westbound Transatlantic

Acknowledgements

The authors are grateful to the journal's Editor and referees for their painstaking work that has led to a much stronger typescript.

\section{Authors' contributions}

Authors are Equally and Indistinguishably Responsible for Typescript. Both authors read and approved the final manuscript.

\section{Authors' information}

None.

Funding

None.

\section{Availability of data and materials}

Available upon Request from the Authors.

\section{Competing interests}

The authors declare that they have no competing interests.

\section{Author details}

${ }^{1}$ Tufts University, Medford, MA 02155, USA. ${ }^{2}$ School of Maritime Economics \& Management, Dalian Maritime University, Dalian, China. ${ }^{3}$ Department of Engineering Technology and Industrial Distribution, Texas A\&M University, College Station, USA.

Received: 17 October 2019 Accepted: 17 December 2019

Published online: 13 January 2020

\section{References}

Beenstock M, Vergottis A (1987) Econometric modeling of world shipping. International studies in economic modelling. London: Chapman and Hall 
Binkley JK, Bessler DA (1983) Expectations in Bulk Ocean shipping: an application of autoregressive modeling. Rev Econ Stat 65(3):516-520

Fair R (1993) Testing the rational expectations hypothesis in macroeconometric models. Oxf Econ Pap 45:169-190 Hansen LP (1982) Large sample properties of generalized method of moments estimators. Econometrica 50:1029-1054

Haralambides HE (2019) Gigantism in container shipping, ports and global logistics: a time-lapse into the future. Marit Econ Logistics 21(1):1-60

Haralambides, H.E., Fusillo, M., Hautau, U., Sjostrom, W. and Veenstra, A.W. (2003) The Erasmus Report: Global Logistics and the Future of Liner Shipping Conferences. Based on the report prepared for the European Commission (Competition Directorate General) in the context of their deliberations concerning the abolition of liner conferences from European trades (Council regulation 4056/86). (An expanded and updated version of that report can be downloaded from: https:// www.researchgate.net/publication/294427101_The_Erasmus_Report_Global_Logistics_and_the_Future_of_Liner_ Shipping_Conferences)

Haralambides HE, Thanopoulou H (2014) The economic crisis of 2008 and world shipping: unheeded warnings. SPOUDAl 64(2):2014

Koopmans T (1939) Tanker Freight rates and tankship building: an analysis of cyclical fluctuations. Netherlands Economics Institute, No. 27. De Erven F. Bohn N.V., Haarlem

Lovell MC (1986) Tests of the rational expectations hypothesis. Am Econ Rev 76(1):110-124

Lucas RE Jr (1972) Econometric testing of the natural rate hypothesis. In: Eckstein O (ed) The econometrics of price determination. Board of Governors, Federal Reserve System, Washington, DC

Lynde C (1990) US industry pricing and rational expectations. Atl Econ J XVIII(4):48-58

Muth JF (1961) Rational expectations and the theory of price movements. Econometrica 29(3):315-335

Orazem P, Miranowski J (1986) An indirect test for the specification of expectation regimes. Rev Econ Stat 68(4):603-609

Puah C-H, Wong S-L, Liew K-S (2013) Testing rational expectations hypothesis in the manufacturing sector in Malaysia. J Bus Econ Manag 14(2):303-316. https://doi.org/10.3846/16111699.2011.631743

Svendsen I (1993) Testing the rational expectations hypothesis using Norwegian microeconomic data. Discussion paper 90. Research Department, Central Bureau of Statistics, Norway

\section{Publisher's Note}

Springer Nature remains neutral with regard to jurisdictional claims in published maps and institutional affiliations.

\section{Submit your manuscript to a SpringerOpen ${ }^{\circ}$ journal and benefit from:}

- Convenient online submission

- Rigorous peer review

- Open access: articles freely available online

- High visibility within the field

- Retaining the copyright to your article

Submit your next manuscript at $\boldsymbol{\nabla}$ springeropen.com 